Int. J. Dev. Biol. 54: 1623-1629 (2010)

doi: $10.1387 /$ ijdb. $103203 y \mathrm{k}$

\title{
Role of the donor nuclei in cloning efficiency: can the ooplasm reprogram any nucleus?
}

\author{
YOKO KATO* and YUKIO TSUNODA \\ Laboratory of Animal Reproduction, College of Agriculture, Kinki University, Nara, Japan
}

\begin{abstract}
Cloning efficiency has not been dramatically improved after the first success of somatic cell nuclear transfer (SCNT) in sheep in 1997. The reasons for the low efficiency of SCNT embryos must be attributed to the insufficient reprogramming of the donor nucleus in ooplasm. It has been clarified that the methylation and acetylation status are disordered in SCNT embryos and the gene expression pattern is different and widely varied in SCNT embryos, compared with fertilized embryos. In this paper, we focused on the role of the donor nuclei in cloning efficiency, and discuss whether ooplasm can reprogram any nucleus.
\end{abstract}

KEY WORDS: cloning, donor nucleus, nuclear transfer, efficiency, reprogram

\section{Introduction}

Despite several attempts to improve the cloning efficiency of somatic cell nuclear transfer (SCNT) since the first successful production of a sheep in 1997 (Wilmut et al., 1997), dramatic improvements have not yet been realized. Reprogramming the meiotic deacetylation process by inhibiting deacetylation with the potent and specific histone deacetylase inhibitor trichostatin A (TSA) has been effective for in vitro and in vivo cloning efficiency (Rybouchkin et al., 2006; Tsuji et al., 2009; Kishigami et al., 2006), but has not induced sufficiently dramatic improvement. Although the low efficiency of SCNT embryos appears to be due to insufficient reprogramming of the donor nucleus in the ooplasm, this has not been clarified and overcoming this insufficient reprogramming presents several challenges. The nuclear reprogramming process is likely to be very complex; upon nuclear transfer, donor chromatin is exposed to the ooplasm (the first and most important reprogramming step), and after artificial activation of SCNT oocytes, reconstituted oocytes begin preimplantation development (the second reprogramming process), including zygotic genome activation, compaction, and the first differentiation into ICM and TE cell lineages. Postimplantation development is the last reprogramming step and is even more complex.

In the first reprogramming process, donor information should be reprogrammed from the somatic type to the embryonic type. Reprogramming factors in the ooplasm have also been examined, and several factors that promote cloning efficiency have been identified (Miyamoto et al., 2007, 2009; Jullien et al., 2010). In the second reprogramming process, SCNT embryos begin to cleave and develop to the blastocyst stage with a time schedule similar to that of fertilized embryos. Although the gene expression pattern of SCNT preimplantation embryos is largely different and varies widely compared with fertilized embryos (Li et al., 2006a,b, 2008), it is not known whether the different gene expression patterns are incompatible with successful SCNT cloning. The last reprogramming process involves very complex fero-maternal communication, an in vivo process that remains unclear. Administration of human chorionic gonadotrophin (hCG) to control the physiology of recipient females was recently reported to improve cloning efficiency (Tsuji et al., 2010).

Several studies have focused on determining which donor cell type or donor cell status is best for successful cloning (Table 1). The state of the donor cell is one of the most important factors for cloning efficiency. In the present study, we discuss mainly the role and effect of the donor nucleus type in cloning efficiency.

\section{Cell cycle combination}

For successful cloning, reconstituted oocytes must carry the diploid DNA contents after artificial activation. In nuclear-transferred blastomeres of preimplantation embryos, donor blastomeres at any cell cycle can be reprogrammed in MII ooplasm; G1 and Mphase donor blastomeres can be reprogrammed in MII ooplasm, and S-phase donor blastomeres can be reprogrammed in activated MII ooplasm, which might be because maturation promot-

Abbreviations used in this paper: SCNT, somatic cell nuclear transfer. *Address correspondence to: Yoko Kato. Laboratory of Animal Reproduction, College of Agriculture, Kinki University, 3327-204, Nakamachi, Nara 631-8505,
Japan. e-mail: yoko@nara.kindai.ac.jp 
ing factor (MPF) activity is decreased during S-phase.

In contrast, when somatic cells are used as donors for nuclear transfer, the cell cycle combination might be important for development. The G0-phase was thought to be the most adequate cell cycle for nuclear reprogramming of the donor nucleus (Campbell, et al., 2006; Wilmut et al., 1997), but it was later clarified that the G1-phase and M-phase are also reprogrammed in MII-phase oocytes and can develop to full-term (Table 1). Even if cells are not induced to the G0-phase by serum starvation or contact inhibition, up to approximately $60 \%$ cells of cultured somatic cells are in the $\mathrm{G} 1$ phase. When donor cells at the G0 and G1-phase are used, emission of the first polar body in reconstituted oocytes must be suppressed by cytochalasin B or a similar chemical to maintain the diploid status of the donor cell in the ooplasm, as in blastomere transfer. When M-phase cells are used as donor cells, as reported in mouse (Ono, 2001a,b) and rat (Zhou, 2003), emission of the

TABLE 1

THE EFFECTS OF DONOR CELL TYPE AND CELL CYCLE COMBINATION BETWEEN DONORS AND RECIPIENTS, ON DEVELOPMENTAL ABILITY OF NT EMBRYOS RECEIVING SOMATIC, EMBRYONIC, ES, EG AND PGC CELLS

\begin{tabular}{|c|c|c|c|c|c|c|c|}
\hline & & Donor cell type & $\begin{array}{l}\text { animal } \\
\text { (donor-recipient) }\end{array}$ & $\begin{array}{l}\text { donor:recipient } \\
\text { cell cycle(stage) }\end{array}$ & $\begin{array}{c}\text { morula-BI } \\
\text { /activated } \\
(\%)\end{array}$ & $\begin{array}{c}\text { live offspring } \\
\text { /ET(\%) }\end{array}$ & Ref. \\
\hline & & mammary gland & sheep & ss1) $5 \mathrm{~d}: \mathrm{MII}$ & 11.7 & 3.4 & Wilmut et al., 1997. \\
\hline & & oviduct & bovine & ss3:4d:MII & 23 & 75 & Kato et al., 1998. \\
\hline & & cumulus & bovine & ss3:4d:MII & 49 & 83 & Kato et al., 1998. \\
\hline & & cumulus & mouse & G0:MII & $39.9-66.9$ & $2-2.5$ & Wakayama et al., 1998. \\
\hline & & follicular epithelial cell & mouse & ss2:9d:MII & 34 & 3 & Kato et al., 1999a. \\
\hline & & tail tip & mouse & ss3:5d:MII & 58.3 & 1 & Wakayama and Yanagimachi, 1999a. \\
\hline & & tail tip & mouse & $?: \mathrm{MII}$ & 49.5 & 1.1 & Wakayama and Yanagimachi, 1999a. \\
\hline & & derived from 11 kinds of tissue(fibroblast) & bovine & G0:MII & $30-53$ & 15 & Kato et al., 2000. \\
\hline & & fibroblast & gaur - bovine & ?:MII & 12 & $2^{2)}$ & Lanza et al., 2000. \\
\hline & & granulosa cell & pig & ss48:72h:MII & $?$ & 7 & Polejaeva et al., 2000. \\
\hline & & cumulus & mouse & G0:M(zygote) & $0(4-$ cell $)$ & 0 & Wakayama et al., 2000. \\
\hline & & granulosa cells & mouflon-sheep & G0:MII & 30 & 14 & Loi et al., 2001. \\
\hline & & cumulus & goat & ss:MII & 7,8 & 1 & Zou et al., 2001 \\
\hline & & cumulus & rabbit & ?:MII & 47 & 1,6 & Chesne et al., 2002. \\
\hline & & lymphocytes & mouse & ?:MII & 5 & $7-67^{3)}$ & Hochedlinger and Jaenisch, 2002. \\
\hline & & lymphocytes & mouse & ?:MII & 5 & $1-10^{4)}$ & Hochedlinger and Jaenisch, 2002. \\
\hline & & cumulus & cat & ?:MII & ? & 33 & Shin et al., 2002. \\
\hline & & fibroblast from mucosa & cat & ?MII & ? & 0 & Shin et al., 2002. \\
\hline & & fibroblast from heart & pig & MII & 6 & 2 & Yin et al., 2002. \\
\hline & & fibroblast & horse & $?:$ MII & 7 & 6 & Galli et al., 2003. \\
\hline & adult & anterior pituitary & goat & ss5:6d: MII & 3 & 17 & Ohkoshi et al., 2003. \\
\hline & & fetal fibroblast & rat & M:MII & - & 2 & Zhou et al., 2003. \\
\hline & & fibroblast & african wild cat-domestic cat & ss $5 \mathrm{~d}: \mathrm{MII}$ & - & 3 & Gomez et al., 2004. \\
\hline & & Bone marrow mesenchyma stem cell & bovine & Go:MII & 24 & 8 & Kato et al., 2004. \\
\hline & & natural killer $\mathrm{T}$ cell & mouse & ?:MII & 71 & $1.1-1.6$ & Inoue et al., 2005. \\
\hline & & skin fibroblast & dog & ?:MII & - & 0,2 & Lee et al., 2005. \\
\hline & & skin fibroblast & wolf-dog & ?:MII & - & 0,8 & Kim et al., 2007. \\
\hline & & cultured cumulus & ferret & ss24h:MII & - & $1.2-1.8$ & Li et al., 2006. \\
\hline Somatic cells & & fibroblast & rabbit & Go:S(2:cell) & 24,5 & 1 & Skrzyszowska et al., 2006. \\
\hline somatic cells & & hematopoietic stem cells & mouse & ?:MII & $4.1-7.9$ & - & Sung et al., 2006. \\
\hline & & hematopoietic progenitor cells & mouse & ?:MII & 10.6 & - & Sung et al., 2006. \\
\hline & & hematopoietic granulocytes & mouse & ?:MII & 34.5 & 1.1 & Sung et al., 2006. \\
\hline & & antler stem cell & red deer & ss $4 \mathrm{~d}: \mathrm{MII}$ & 22 & 13 & Berg et.al., 2007. \\
\hline & & tail tip & mouse & M:M(zygote) & 3 & - & Egli et.al., 2007. \\
\hline & & fibroblast & mouse & M:M(zygote) & - & $?^{5)}$ & Egli et.al., 2007. \\
\hline & & keratinocytes & mouse & ?:MII & 56 & 2 & Li et al., 2007. \\
\hline & & cultured granulosa & buffalo & ss72h:MII & 22,2 & 10 & Shi et al., 2007. \\
\hline & & cumulus & sand cat-domestic cat & ?:MII & $15-16$ & $0.3-1.8$ & Gomez et al., 2008. \\
\hline & & fibroblast & Pyrenean Ibex-domestic goat & 72h:MII & 65,3 & 0,6 & Folch et al., 2009. \\
\hline & & cultured cumulus & camel & ss72h:MII & $34-44$ & 4 & Wani et.al., 2010. \\
\hline & & iPS & mouse & M:MII & 77.7 & 3.5 & Kou et al., 2010. \\
\hline & & derived from 16 kinds of tissue(fibroblast) & bovine & G0:MII & $25-47$ & 14 & Kato et al., 2000. \\
\hline & newborn/y & Sertoli & mouse & ?:MII & $23-60$ & $1.2-4.5$ & Ogura et al., 2000. \\
\hline & & neural stem cell & mouse & ?:MII & - & $0.5-1.1$ & Mizutani et al., 2006. \\
\hline & & fetal fibroblast & goat & ss $7 \mathrm{~d}: \mathrm{MII}$ & ? & 2,1 & Baguisi et al., 1999. \\
\hline & & fetal fibroblast & goat & ss 7d:Teloll & ? & 5,2 & Baguisi et al., 1999. \\
\hline & & genital ridge cells & pig & 0:4d:MII & $4-8$ & 0,7 & Betthauser, 2000. \\
\hline & & fibroblast & pig & 0:4d:MII & $4-8$ & 0,3 & Betthauser, 2000. \\
\hline & & fetal fibroblast & pig & 16d:MII & $1-31.2$ & 0,9 & Onishi et al., 2000. \\
\hline & fetus & 10 kinds of tissue(fibroblast) & bovine & G0:MII & $23-46$ & 8 & Kato et al., 2000 \\
\hline & & fibroblast & mouse & M:MII & $29-37$ & $0.7-3$ & Ono et al.,, 2001b. \\
\hline & & neural cells & mouse & ?:MII & 37 & 5.5 & Yamazaki et al., 2001. \\
\hline & & neural cells, premature-early differentiated & mouse & ?:MII & 36 & 12 & Yamazaki et al., 2001. \\
\hline & & neural cells, differentiated & mouse & ?:MII & 23 & 5 & Yamazaki et al., 2001. \\
\hline & & fetal fibroblast & mule-horse & ?:MII & - & 0,3 & Woods et al., 2003. \\
\hline & & keratinocytes & mouse & ?:MII & 54 & 2 & Li et al., 2007. \\
\hline
\end{tabular}




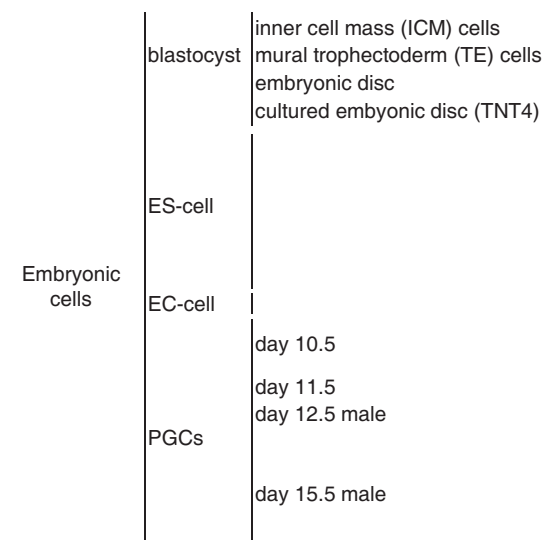

\begin{tabular}{llccl} 
mouse & G16):MII & $23-64$ & 8 & Tsunoda and Kato, 1998. \\
mouse & G16):MI & $32-62$ & 11 & Tsunoda and Kato, 1998. \\
sheep & ss 5 d:MII & $6.7-21$ & 11 & Campbell et al., 1996. \\
sheep & ss 2d : MII & $9.2-50$ & 15 & Campbell et al., 1996. \\
mouse & small size:MII & 16.5 & 5 & Wakayama et al., 1999b. \\
mouse & large size:MII & 36.8 & 3 & Wakayama et al., 1999b. \\
mouse & M:MII & $34-88$ & $2-6$ & Amano et al., 2001. \\
mouse & M:MII & 70 & 10 & Ono et al., 2001a. \\
mouse & M:MII & $51^{7)}$ & $16^{7)}$ & Ono et al., 2001a. \\
mouse & M:M(zygote & 10 & 5 & Egli et.al., 2007. \\
mouse & ?:MII & $0-29.7$ & $0^{8)}$ & Chang et.al., 2010. \\
mouse & G1:M & - & 0.4 & Miki et al., 2005. \\
mouse & M:M & - & 0.4 & Miki et al., 2005. \\
mouse & G0:M(zygote) & 14 & - & Kato and Tsunoda, 1995a. \\
mouse & G0:S(2:cell) & 2 & - & Kato and Tsunoda, 1992. \\
mouse & G0:S(2:cell) & 7 & - & Kato and Tsunoda, 1992. \\
mouse & G0:M(zygote) & 57 & - & Kato and Tsunoda, 1995a. \\
mouse & G0:MII & 58 & $(3)^{10)}$ & Kato and Tsunoda, 1995b., \\
mouse & G0:MII & $47-66$ & $(57)^{11)}$ & Tsunoda and Kato, 1995. \\
\hline
\end{tabular}

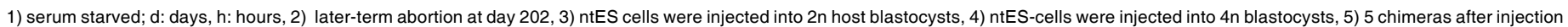

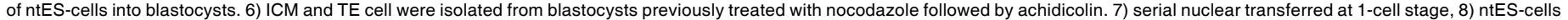
were injected into $4 \mathrm{n}$ bl;astocysts, 10) day 10.5 chimera after serial nuclear trasnfer at the 2-cell stage, 11) day 10.5 fetuses.

second polar body after artificial activation is essential to maintain the diploid status in the ooplasm. This differs from blastomere transfer, because somatic cells at the S-phase do not develop in activated ooplasm. Also, when G0/G1-phase and M-phase donor cells are transferred to activated ooplasm, the in vitro developmental ability of reconstituted oocytes is significantly decreased (Tani et al., 2003).

The Table summarizes the effect of the cell cycle of the donor and recipient and of the donor cell types on the development of manipulated embryos. The first report of each animal species and the specific cell cycle combination of the donor and recipient was selected from the vast literature. As shown in Table, a G0/G1 donor with MII recipient ooplasm was used in almost all successful reports.

There have been some attempts to use fertilized oocytes such as zygotes and 2-cell embryos as SCNT recipients, but the success has been limited. Zygotes at the S-phase seem to support the development of SCNT up to the 4-cell stage and then development stops (Wakayama et al., 2000). Zygotes at the Mphase seem to support the development of SCNT to the blastocyst stage (Egli et al., 2007), but if embryonic stem (ES) cells are used, zygotes at the M-phase can develop to full term after embryo transfer to foster mothers (Egli et al., 2007).

When primordial germ cells at the arrested stage obtained from day 15.5 fetuses or at the mitotic phase obtained from day 11.5 fetuses were fused with enucleated zygotes at the M-phase (Kato and Tsunoda, 1995a) and/or enucleated blastomeres of one of the 2-cell embryos at the late S-phase (Kato and Tsunoda, 1992), reconstituted zygotes or chimeric 2-cell embryos(Kato and Tsunoda, 1992) developed to the blastocyst stage. Moreover, in rabbit, chimeric embryos, i.e., adult fibroblast cells fused with one enucleated blastomere of a 2-cell embryo, develop to chimeric offspring (Skrzyszowska et al., 2006).

Based on these studies, MII oocytes might possess some reprogramming factors in the ooplasm (Miyamoto et al., 2009), but gradually lose these reprogramming factors in the cytoplasm after fertilization or artificial activation (Tani et al., 2003). We examined the effect of ooplasm aging on the developmental potential of SCNT embryos in bovine (Tani et al., 2003) and in mouse (Liu et al., 2007). When bovine cumulus cells at the G0- phase and M-phase are fused every hour after activation for $6 \mathrm{~h}$, the potential to develop into blastocysts after SCNT gradually decreased with time after activation. Ooplasm $2 \mathrm{~h}$ and more after activation did not support the development of G0-phase cumulus nuclei to blastocysts. When M-phase cumulus cells were fused, the ability to develop into blastocysts dramatically decreased beginning at $6 \mathrm{~h}$ postactivation. These findings clearly demonstrate that some reprogramming factors present in the ooplasm decrease after artificial activation. We isolated some reprogramming factors in the ooplasm before activation, and identified one of the candidate reprogramming factors as TCTP (Tani et al., 2007), which expressed in ooplasm, but is no longer present in activated ooplasm as the same type. Although, oocytes injected with TCTP peptide after SCNT produce much healthier offspring in bovine than in non-injected oocytes, (Tani et al., 2007), the role played by TCTP in the whole reprogramming process remains unclear.

\section{Donor cell type}

After the first report in which mammary gland cells were used as the donor cells, cumulus cells have been the most popular donor cell type in SCNT because of the experimental convenience (Table 1). Many attempts have been made to determine the most efficient donor cell types, especially for bovine and mouse. To examine which cell types are the most successful for SCNT in bovine, we compared the development potential of 39 cell types from adults, newborns, and fetuses of both sexes, but there was no big difference (Kato et al., 2000). When tissue or biopsy samples were used for the cell culture, fibroblast cells were the most common cell type to easily increase. Cells that were not identified as a specific cell before nuclear transfer were categorized as fibroblast cells. As shown in the table, although the developmental potential was higher in bovine compared with mice, the overall conclusion is that cloning efficiency is similar among somatic cell types. Although some types of stem cell, such as bone marrow mesenchymal stem cells (Kato et al., 2004), neural stem cells (Mizutani et al., 2006), and hematopoietic stem cells (Sung et al., 2006), might be adequate for cloning, the results do not indicate equivalent efficiency suggesting that the low 
efficiency of SCNT must not depend on the cell type, but that ooplasm alone is also not sufficient for complete reprogramming of the somatic nucleus. To improve the efficiency of SCNT cloning, several possibilities are considered.

When male primordial germ cells on day 15.5 arrested at the G0-phase of the cell cycle were used as donor cells, nucleartransferred oocytes developed to blastocysts, but after their transfer to recipient mice, they stopped developing at around day 10.5 due to the lack of a proper imprint (Tsunoda and Kato, 1995; Kato and Tsunoda, 1999b; Kato et al., 1999b). Later, Miki et al.,2005) demonstrated that PGCs on day 10.5 developed to term after nuclear transfer.

Based on these results, epigenetic modification of DNA such as methylation in imprinted genes might not be reprogrammed by the ooplasmic factor(s) alone. If donor cell chromatin undergoes epigenetic modification in genes important for development, such as imprinting before nuclear transfer, nuclear-transferred oocytes must be very difficult to completely reprogram. It might be suggested that imprinting status is more important for the success of cloning than the origin of the donor cells. It is possible that successful cloning requires the use of donor cells with an adequate methylation pattern that are then reprogrammed in the ooplasm and develop to term.

\section{Cytoplasmic factors}

In conducting nuclear transfer, cytoplasmic factors of donor cells often contaminate the recipient ooplasm. Somatic cytoplasmic factors affect the developmental potential of not only nucleartransferred embryos but also parthenogenetic oocytes (Takeda et al., 2005, 2010) and fertilized oocytes (Thuan et al., 2006). Thuan et al. (2006) also demonstrated that the injection of cumulus cytoplasm into oocytes before fertilization induced a decrease in preimplantation development and impaired full-term development. When isolated mitochondria from ear epithelial cells in the G0-phase were injected into mouse oocytes, the developmental potential of parthenogenones into blastocysts was significantly decreased (Takeda et al., 2010), suggesting that mitochondrial heteroplasmy or foreign mitochondria introduction affects the developmental potential of parthenogenetic oocytes.

In SCNT, donor mitochondria comprise only about $1 \%$, which is difficult to detect. In some cases, however, the amount of mitochondria from donor somatic cells increased and survived to become clones (Takeda et al., 2003). It has remained unclear how mitochondria heteroplasmy affects SCNT development.

In nuclear transfer, serial nuclear transfer at the late pronucleus (Ono et al., 2001b) or 2-cell stages in the mouse (Kato et al., 1999a), during which zygotic genome activation has occurred in the mouse, improves the development of SCNT embryos. The serial nuclear transfer has mainly two effective meanings; dilution of the donor cytoplasmic factors incorporated in the ooplasm, and fertilized cytoplasm after zygotic genome activation must be much better than parthenogenetic ooplasm (Kato et al., 1999a).

\section{Direct reprogramming of somatic cells into pluripotency}

The term "reprogramming" may be used to refer to either the induction of totipotency(Tsunoda and Kato, 2002), leading to successful cloning or the induction of pluripotent capabilities.
Tada et al.,2001) demonstrated that somatic cells such as lymphocytes fused with ES cells become pluripotent. Activation of the Oct4 gene and reactivation of the $X$ chromosome in lymphocyte nuclei in hybrid cells results in chimeric fetuses. These acquired characteristics in the lymphocytes are very similar to that of ES cells. Tada et al. $(1997,2001)$ also demonstrated that embryonic germ cells have more developmental potential than ES cells; the methylation status of embryonic germ cells is downregulated compared to that of ES cells and therefore the imprint of ES cells is erased after fusion in the hybrid cells. Although, it is not clear which factors contribute to controlling the methylation pattern and to erasing the imprint from ES cells, factor(s) including imprint status, in EG-cells and PGCs seemed to be dominant compared with that from ooplasm and ES-cells.

Somatic cells were recently directly reprogrammed (Mitalipov and Wolf, 2009) to induce pluripotency in cells in vitro, termed induced pluripotent stem (iPS) cells (Takahashi and Yamanaka, 2006) and MUSE cells (Kuroda et al., 2010). When iPS cells were used as donor cells, the cloning efficiency was slightly improved to a level between that of somatic cells and ES cells (Kou et al.,2010). MUSE cells can be isolated from cultured skin fibroblasts and bone marrow stromal cells, or directly from bone marrow aspirates. MUSE cells can be produced without gene transfer and are capable of self-renewal and expression of a set of genes associated with pluripotency. Moreover, they are nontumorigenic stem cells with the ability to generate multiple cell types of the three germ layers. At present, MUSE cells show low proliferation activity, but will be useful as candidate SCNT donors, especially in domestic animals, because the produced cloned animals are not transgenic.

One possibility is that clones are produced via nuclear transfer of ES cells (ntES-cells). Although ES cells have varied gene expression patterns (Furusawa et al., 2006), the cloning efficiency of ES cells is higher (12.3\%-33\%) than that of somatic cells (1.1\%-3.4\%, Mizutani et al., 2008; Amano et al., 2001), and may be useful for improving SCNT efficiency. But, three steps are needed for using ntES cells as donors for the second NT; first, NT with somatic cells, then ES cell establishment from SCNT blastocysts, and last, the second NT.

Because the direct reprogramming of somatic cells induces pluripotency, such as in ES cells or somatic cells in vitro, direct reprogrammed somatic cells might be interesting SCNT donor candidates.

\section{Pre- and post-treatment of SCNT embryos}

Treatment of reconstituted oocytes with TSA, which inhibits the activity of classical histone deacetylases, improves the potential of young to develop into mice. TSA treatment might also stimulate DNA demethylation (Cervoni \& Szyf, 2001; Geiman \& Robertson, 2002; Kishigami et al., 2006), leading to improved reprogramming.

The DNA methyltransferase inhibitor 5-aza-2'-deoxycytidine (5-aza-dC) relaxes epigenetic marks of differentiated somatic cells. Pretreatment of somatic cells with 5-aza-dC, however, does not increase but rather decreases development potential due to its toxicity (Jones et al., 2001; Viggnon et al., 2002; Enright et al., 2003; 2005; Shi et al., 2003). Moreover, treatment of reconstituted oocytes with 5-aza-dC does not improve the developmental 
potential of SCNT embryos. 5-aza-dC might be too toxic for cells and long-term culture is not adequate for cells and embryos (Tsuji et al.2009).

The morphology of SCNT blastocysts is not a criteria of embryo quality, because even SCNT embryos with a visually-perfect morphology under a microscope develop at a very low rate to fullterm. The developmental ability of SCNT embryos and ES cell nuclear-transferred embryos gradually decreases in vivo (Amano et al., 2001; Yabuuchi et al., 2001) Many attempts to improve the potential of SCNT have focused mainly on the preimplantation stages, and not focused on the postimplantation stages. Ewes carrying SCNT clone pregnancies have significantly lower serum progesterone levels than ewes carrying control pregnancies, suggesting that a low serum P4 level is one reason for the low potential of SCNT embryos to reach full term (Alexander et al., 2008). Enhancement of the recipient by daily injection of hCG from day 3.5 to day 6.5 of pregnancy after embryo transfer of SCNT significantly increases the implantation and fetal development rates compared to controls (Tsuji et al., 2010). The potential of SCNT embryos to develop to full term, however, was not greater than that of controls, even if hCG administration was continued to day 11.5 or day 17.5 and progesterone was administered from day 7.5 to day 17.5 after hCG injection. These findings demonstrated that injection of hCG to recipients protects the in vivo development of SCNT embryos until day 10.5, but other treatment is necessary to support the progression of the embryos to full-term development.

\section{Selection of SCNT embryos before transfer}

Although the morphologic appearance of SCNT embryos does not differ from that of in vitro-fertilized embryos, the potential to develop to term dramatically differs between SCNT and IVF embryos (Li et al., 2005, 2006a, b, 2008; Kato et al., 2007.). Markers that will be useful for predicting the potential of NT embryos to develop into young are needed. We examined the relation between the morphology of embryos with gene expression of development-related genes, such as Oct 4, Nanog, Stat3, FGF4, Stella, and Sox2 (Li et al., 2006a,b). In that study, six kinds of blastocysts were produced; in vivo fertilized/in vivo-developed, in vivofertilized/in vitro-developed, pronuclear exchanged, morula blastomere NT, ES-NT, and cumulus cell NT. Based on the small variations in the gene expression levels among the in vivodeveloped blastocysts, and the significant differences in gene expression between in vivo-developed (high developmental potential), and ES cell and cumulus cell NT blastocysts (low developmental potential), the downregulation of Sox 2 and Oct4 genes is considered to be a candidate marker for the low potential of NT embryos to develop into young. A method of preselecting donor cells before SCNT is needed (Furusawa et al., 2006)

\section{Interspecies nuclear transfer}

The use of SCNT methods has been extended to a wide variety of fields. Interspecies nuclear transfer of endangered species is a new purpose for SCNT (Beyhan et al., 2007). Many attempts have been taken to produce animals by interspecies nuclear transfer, developmental potential of interspecies nuclear-transferred embryos was very low, and full-term development was very limited (Beyhan et al., 2007). The interactions between the donor nucleus and recipient ooplasm should be matched for development. Mitochondrial interaction, transcription, and translation, which occur in reconstituted ooplasm, must be overcome. As shown in the table, several experiments using interspecies SCNT have succeeded.

\section{Conclusion}

Despite continuing problems with SCNT, it is also clear that SCNT can be used to produce healthy cloned animals. After the first successful SCNT more than 10 years ago, researchers have tried several methods to improve the efficiency of SCNT. Nevertheless, the efficiency remains low. It is still unclear if the successful cloning was derived from the elite donor cells were happened to be selected as nuclear donor, or some kinds of donor nucleus happened to be reprogrammed in ooplasm. Ooplasm reprogramming should be further investigated as a factor in the direct reprogramming of somatic cells to become pluripotent. If ooplasm which can reprogram any donor nucleus, it will be much useful for extended to a wide variety of fields more than expection, although it is still in the beginning.

\section{Acknowledgements}

This work was supported by the Ministry of Education, Science, and Culture (21028022).

\section{References}

ALEXANDER, B., COPPOLA, G., MASTROMONACO, G.F., John, E.St., Reyes, E.R., Betts, D.H., King, W.A. (2008). Early pregnancy diagnosis by serum progesterone and ultrasound in sheep carrying somatic cell nuclear transferderived pregnancies. Reprod Domest Anim 43: 207-211.

AMANO,T., TANI,T., KATO,Y., TSUNODA,Y. (2001). Mouse cloned from embryonic stem(ES) cells synchronizing in metaphase with nocodazole. $J$ Exp Zool 289: 139-145.

BAGUISI, A., BEHBOODI, E., MELICAN, D.T., POLLOCK, J.S., DESTREMPES, M.M., CAMMUSO,C., WILLIAMS, J.L., NIMS, S.D., PORTER, C.A., MIDURA P., PALACIOS, M.J., AYRES,S.L., DENNISTON, R.S., HAYES,M.L., ZIOMEK, C.A., MEADE,H.M., GODKE, R.A., GAVIN,W.G., OVERSTROM, E.W., ECHELARD, Y. (1999). Production of goats by somatic cell nuclear transfer. Nat Biotechnol 17: 456-461.

BERG,D.K., Li,C., ASHER, G., WELLS, D.N., OBACK, B. (2007). Red deer cloned from antler stem cells and their differentiated progeny. Biol Reprod 77: 384-394.

BETTHAUSER, J., FORSBERG, E., AUGENSTEIN, M., CHILDS L., EILERTSEN K., ENOS, J., FORSYTHE,T., GOLUEKE, P., JURGELLA, G., KOPPANG, R., LESMEISTER, T., MALLON, K., MELL,G., MISICA, P., PACE, M., PFISTERGENSKOW, M., STRELCHENKO, N., VOELKER,G, WATT,S., THOMPSON,S.,BISHOP,M. (2000). Production of cloned pigs from in vitro systems. Nat Biotechnol 18: 1055-1059.

BEYHAN,Z., IAGER,A.E., CIBELLI,J.B. (2007). Interspecies nuclear transfer: implications for embryonic stem cell biology. Cell Stem Cell 1: 502-512.

CAMPBELL,K.H., McWHIR,J., RITCHIE, W.A., WILMUT, I. (1996). Sheep cloned by nuclear transfer from a cultured cell line. Nature 380: 64-66.

CERVONI, N., SZYF, M. (2001). Demethylase activity is directed by histone acetylation. J Biol Chem 276: 40778-40787.

CHANG, G., MIAO, Y.L., ZHANG, Y., Liu,S., KOU, Z., DING, J., CHEN, D.Y., SUN Q.Y., Gao, S. (2010). Linking incomplete reprogramming to the improved pluripotency of murine embryonal carcinoma cell-derived pluripotent stem cells. PLoS One. 5:e10320.

CHESNE, P., ADENOT, P.G., VIGLIETTA, C., BARATTE, M., BOULANGER, L., RENARD, J.P. (2002). Cloned rabbits produced by nuclear transfer from adult somatic cells. Nat Biotechnol. 20: 366-369. 
EGLI, D., ROSAINS, J., BIRKHOFF, G., EGGAN, K. (2007). Developmental reprogramming after chromosome transfer into mitotic mouse zygotes. Nature 447: 679-685.

ENRIGHT, B.P., KUBOTA,C., YANG,X., TIAN, X.C. (2003). Epigenetic characteristics and development of embryos cloned from donor cells treated by trichostatin A or 5-aza-2' -deoxycytidine. Biol Reprod 69: 896-901.

ENRIGHT, B.P., SUNG,L.Y., CHANG,C.C., YANG,X., TIAN,X.C. (2005). Methylation and acetylation characteristics of cloned bovine embryos from donor cells treated with 5- aza-2 2 -deoxycytidine. Biol Reprod. 72: 944-948.

FOLCH, J., COCERO, M.J., CHESNE, P., ALABART, J.L., DOMINGUEZ, V., COGNIE, Y., ROCHE, A., FERNANDEZ-ARIAS,A., MARTI, J.I., SANCHEZ,P., ECHEGOYEN, E., BECKERS,J.F.,BONASTRE, A.S., VIGNON, X. (2009). First birth of an animal from an extinct subspecies (Capra pyrenaica pyrenaica) by cloning. Theriogenology 71: 1026-1034.

FURUSAWA, T., IKEDA,M., INOUE,F., OHKOSHI, K., HAMANO, T., TOKUNAGA, T. (2006). Gene Expression Profiling of Mouse Embryonic Stem Cell Subpopulations. Biol Reprod 75: 555-561.

GALLI, C., LAGUTINA, I., CROTTI, G., COLLENONI, S., TURINI, P., PONDERATO, N., DUCHI, R., LAZZARI, G.,(2003). Pregnancy: a cloned horse born to its dam twin. Nature 424: 635.

GEIMAN,T.M.,ROBERTSON, K.D. (2002). Chromatin remodeling, histone modifications and DNA methylation- how does it all fit together? J Cell Biochem 87: 117-125.

GOMEZ, M.C., POPE,C.E., GIRALDO,A., LYONS,L.A., HARRIS,R.F., KING, A.L., COLE, A., GODKE,R.A., DRESSER, B.L. (2004). Birth of African Wildcat cloned kittens born from domestic cats. Cloning Stem Cells 6: 247-258.

GOMEZ, M.C., POPE,C.E., KUTNER,R.H., RICKS,D.M., LYONS, L.A., RUHE, M., DUMAS, C., LYONS,J., LOPEZ, M., DRESSER, B.L., REISER, J. (2008). Nuclear transfer of sand cat cells into enucleated domestic cat oocytes is affected by cryopreservation of donor cells. Cloning Stem Cells. 10: 469-483.

HOCHEDLINGER,K., JAENISCH,R. (2002). Monoclonal mice generated by nuclear transfer from mature $B$ and T donor cells. Nature 415: 1035-1038.

INOUE,K., WAKAO,H., OGUNOKI,N., MIKI,H., SEINO,K., NAMBU-WAKAO,R., NODA,S., MIYOSHI, H.,KOSEKI,H.,TANIGUCHI,M., OGURA,A. (2005). Generation of cloned mice by direct nuclear transfer from natural killer T cells. Curr Biol 15: 1114-1118.

JONES, K.L., HILL, J., SHIN, T.Y., LUI, L.,WESTHUSIN, M. (2001). DNA hypomethylation of karyoplasts for bovine nuclear transfer. Mol Reprod Dev60: 208-213.

JULLIEN,J., ASTRAND,C., HALLEY-STOTT,R.P., GARRETT,N., GURDON,JB. (2010). Characterization of somatic cell nuclear reprogramming by ooytes in which a linker histone is required for pluripotency gene reactivation. Pceed Natl Acad Sci 107: 5483-5488.

KATO,Y., TSUNODA,Y. (1992). Nuclear transplantation of mouse fetal germ cells into enucleated two-cell embryos. Theriogenology 37: 769-778.

KATO,Y., TSUNODA,Y. (1995a). Nuclear transfer of inner cell mass cells and fetal germ cells at a different cell cycle into enucleated zygotes at M-phase in the mouse. J Reprod Dev 41: 345-351.

KATO,Y., TSUNODA,Y. (1995b). Germ cell nuclei of male fetal mice can support development of chimeras to midgestation following serial transplantation. Development 121: 779-783.

KATO,Y., TANI,T., SOTOMARU,Y., KUROKAWA,K.,KATO,J, DOGUCHI,H.,YASUE,H., TSUNODA,Y. (1998). Eight calves cloned from somatic cells of a single adult. Science 282: 2095-2098.

KATO,Y., YABUUCHI,A., MOTOSUGI, N., KATO,J., TSUNODA,Y. (1999a). Developmental potential of mouse follicular epithelial cells and cumulus cells after nuclear transfer. Biol Reprod 61: 1110-114.

KATO,Y., RIDEOUT III,W.M., HILTON,K., BARTON,S.C., TSUNODA,Y., SURANI,M.A. (1999). Developmental potential of mouse primordial germ cells. Development 126: 1823-1832.

KATO,Y., TANI, T., TSUNODA,Y. (2000). Cloning of calves from various somatic cell types of male and female adult, newborn and fetal cows. J Reprod Fertil 120: 231-237.

KATO, Y., IMABAYACHI,H., MORI,T., TANI,T., TANIGUCHI, M., HIGASHI,M., MATSUMOTO,M., UMEZAWA,A., TSUNODA,Y. (2004). Nuclear transfer of adult bone marrow mesenchymal stem cells: developmental totipotency of tissue-specific stem cells from an adult mammal. Biol Reprod. 70: 415-418.

KATO,Y., LI,X.P., AMARNATH, D., USHIZAWA,K., HASHIZUME,K., TOKUNAGA,T., TANIGUCHI,M., TSUNODA,Y. (2007). Comparative gene expression analysis of bovine nuclear-transferred embryos with different developmental potential by cDNA microarray and real-time PCR to determine genes that might reflect calf normality. Cloning and Stem Cells 9: 495-511.

KIM,M.K., JANG,G., OH,H.J., YUDA,F., KIM,H.J., HWANG, W.S., HOSSEIN, M.S., KIM, J.J., SHIN, N.S., KANG, S.K., LEE, B.C. (2007). Endangered wolves cloned from adult somatic cells. Cloning Stem Cells 9: 130-137.

KISHIGAMI,S., THUAN,N.V., HIKICHI,T., OHTA,H., WAKAYAMA,S.,MIZUTANI,E., WAKAYAMA,T. (2006). Epigenetic abnormalities of the mouse paternal zygotic genome associated with microinsemination of round spermatids. Dev Biol289: 195-205.

KOU,Z., KANG, L., YUAN,Y., TAO,Y., ZHANG,Y., WU, T., HE,J., WANG, J., LIU, Z., GAO, S. (2010). Mice Cloned from Induced Pluripotent Stem Cells (iPSC). Biol Reprod 83: 238-243 (doi: 10.1095/ biolreprod.110.084731)

KURODA,Y., KITADA,M., WAKAO,S., NISHIKAWA,K., TANIMURA,K., MAKINOSHIMA, H., GODA,M., AKASHI,H., INUTSUKA,A., NIWA,A., SHIGEMOTO,T., NABESHIMA,Y., NAKAHARA,T.,NABESHIMA,Y., FUJIYOSHI,Y., DEZAWA,M. (2010). Unique multipotent cells in adult human mesenchymal cell populations. Proc Natl Acad Sci USA. 107: 8639-8643.

LANZA,R.P., CIBELLI,J.B., DIAZ,F., MORAES,C.T., FARIN,P.W., FARIN,C.E., HAMMER,C.J., WEST, M.D., DAMIANI,P. (2000). Cloning of an endangered species (Bos gaurus) using interspecies nuclear transfer. Cloning 2: 79-90.

LEE,B.C., KIM, M.K., JANG, G., OH, H.J., YUDA, F., KIM,H.J., HOSSEIN, M.S., KIM,J.J., KANG, S.K., SCHATTEN, G., HWANG, W.S. (2005). Dogs cloned from adult somatic cells. Nature 436: 641 .

LI, J., GRECO, V., GUASCH, G., FUCHS, E., MOMBAERTS, P. (2007). Mice cloned from skin cells. Proc Natl Acad Sci USA 104: 2738-2743.

LI,X.P., KATO,Y., TSUNODA, Y. (2005). Comparative analysis of developmentrelated gene expression in mouse preimplantation embryos with different developmental potential. Mol Reprod Dev 72: 152-160.

LI,X.P., AMARNATH, D., KATO.Y., TSUNODA,Y. (2006a). Analysis of development-related gene expression in cloned bovine blastocysts with different developmental potential. Cloning Stem Cells 8: 41-50.

LI,X.P., KATO,Y., TSUNODA, Y. (2006b). Comparative Studies on the mRNA Expression of Development-Related Genes in an Individual Mouse Blastocyst with Different Developmental Potential. Cloning and Stem Cells 8: 214-224.

LI,X.P., KATO,Y., TSUJI,Y., TSUNODA, Y. (2008). The effect of trichostatin A on mRNA expression of chromatin structure-, DNA methylation-, and development-related genes in cloned mouse blastocysts. Cloning and stem Cells 10 : 133-142.

LI,Z., SUN, X., CHEN, J., LIU, X., WISELY, S.M., ZHOU, Q., RENARD, J.P., LENO,G.H., ENGELHARDT, J.F. (2006). Cloned ferrets produced by somatic cell nuclear transfer. Dev Biol 293: 439-448.

LIU,G, KATO,Y., TSUNODA,Y. (2007). Aging of recipient oocytes reduces the development of cloned embryos receiving cumulus cells. J Reprod Develop 53: 785-790.

LOI,P., PTAK,G., BARBONI,B., FULKA,J.JR., CAPPAI,P., CLINTON,M. (2001). Genetic rescue of an endangered mammal by cross-species nuclear transfer using post-mortem somatic cells. Nat Biotechnol 19: 962-964.

MIKI,H., INOUE,K., KOHDA,T., HONDA,A., OGONUKI,N., YUZURIHA,M., MISE,N., MATSUI,Y., BABA,T., ABE,K., ISHINO,F., OGURA,A. (2005). Birth of mice produced by germ cell nuclear transfer. Genesis 41: 81-86.

MITALIPOV,S.,WOLF,D. (2009). Totipotency, pluripotency and nuclear reprogramming.Adv Biochem Eng Biotechnol 114: 185-199.

MIYAMOTO,K., FURUSAWA,T., OHNUKI,M., GOEL,S., TOKUNAGA, T., MINAMI,N., YAMADA,M., OHSUMI,K., IMAI,H. (2007). Reprogramming Events of Mammalian Somatic Cells Induced by Xenopus laevis Egg Extracts. Mol Reprod Dev 74: 1268-1277.

MIYAMOTO,K., TSUKIYAMA,T., YANG,Y., LI,NINGi, MINAMI,N., YAMADA,M. IMAI,H. (2009). Cell-Free Extracts from Mammalian Oocytes Partially Induce Nuclear Reprogramming in Somatic. Biol Reprod 80: 935-943.

MIZUTANI,E.E, OHTA,H., KISHIGAMI,S., VAN, THUAN, N., HIKICHI,T. WAKAYAMA,S., KOSAKA,M., SATO,E., WAKAYAMA,T. (2006). Developmental ability of cloned embryos from neural stem cells. Reproduction 132: 849- 
857.

MIZUTANI,E., ONO,T.,LI,C., MAKI-SUETSUGU,R., WAKAYAMA,T. (2008) Propagation of senescent mice using nuclear transfer embryonic stem cell lines. Genesis. 46: 478-483.

OGURA,A, INOUE, K., TAKANO, K., WAKAYAMA,T., YANAGIMACHI,R. (2000). Birth of mice after nuclear transfer by electrofusion using tail tip cells. Mol Reprod Dev 57: 55-59.

OHKOSHI,K., TAKAHASHI,S., KOYAMA,S., AKAGI,S., ADACHI,N., FURUSAWA,T., FUJIMOTO,J.,TAKEDA,K.,KUBO,M., IZAIKE,Y., TOKUNAGA,T(2003). In vitro oocyte culture and somatic cell nuclear transfer used to produce a live-born cloned goat. Cloning Stem Cells. 5: 109-115.

ONISHI,A., IWAMOTO,M., AKITA,T., MIKAWA,S., TAKEDA,K., AWATA,T., HANADA,H., PERRY,A.C. (2000). Pig cloning by microinjection of fetal fibroblast nuclei. Science 289: 1188-1190.

ONO,Y., SHIMOZAWA,N., MUGURUMA,K., KIMOTO,S, HIOKI,K., TACHIBANA,M, SHINKAI,Y., ITO,M., KONO,T. (2001a). Production of cloned mice from embryonic stem cells arrested at metaphase. Reproduction 122: 731-736.

ONO,Y., SHIMOZAWA,N., ITO,M., KONO,T. (2001b). Cloned mice from fetal fibroblast cells arrested at metaphase by a serial nuclear transfer. Biol Reprod 64: 44-50.

POLEJAEVA,I.A., CHEN,S.H., VAUGHT,T.D., PAGEMR.L., MULLINS,J., BALL,S., DAI,Y., BOONE,J., WALKER,S., AYARES,D.L., COLMAN,A., CAMPBELL,K.H. (2000). Cloned pigs produced by nuclear transfer from adult somatic cells. Nature 407: 86-90.

RYBOUCHKIN,A., KATO,Y., TSUNODA,Y. (2006). Role of histone acetylation in reprogramming of somatic nuclei following nuclear transfer. Biol Reprod 74: 1083-1089.

SHI,D., LU,F., WEI,Y., CUI,K., YANG,S., WEI, J., LIU,Q. (2007). Buffalos (Bubalus bubalis) cloned by nuclear transfer of somatic cells. Biol Reprod 77: 285-291.

SHI,W., ZAKHARTCHENKO,V., WOLF,E. (2003). Epigenetic reprogramming in mammalian nuclear transfer. Differentiation 71: 91-113.

SHIN,T., KRAEMER,D., PRYOR,J., LIU,L., RUGILA,J., HOWE,L., BUCK,S., MURPHY,K., LYONS,L., WESTHUSIN,M. (2002). A cat cloned by nuclear transplantation. Nature 415: 859

SKRZYSZOWSKA,M., SMORAG,Z., SBOMSKI,R., KATSKA-KSIAZKIEWICZ,L., KALAK,R., MICHALAK,E., WIELGUS,K., LEHMANN,J., LIPINSKI,D., SZALATA,M., PBAWSKI,A., SAMIEC,M., JURA,J., GAJDA,B., RYNSKA,B., PIENKOWSKI,M. (2006). Generation of transgenic rabbits by the novel technique of chimeric somatic cell cloning. Biol Reprod. 74: 1114-1120.

SUNG,L.Y., GAO,S., SHEN,H., YU, H., SONG, Y., SMITH, S.L., Chang,C.C. INOUE,K., KUO,L., LIAN,J., LI,A., TIAN,X.C., TUCK,D.P., WEISSMAN,S.M., YANG,X., CHENG,T. (2006). Differentiated cells are more efficient than adult stem cells for cloning by somatic cell nuclear transfer. Nat Genet 38: 1323-1328.

TAKAHASHI,K., YAMANAKA,S. (2006). Induction of pluripotent stem cells from mouse embryonic and adult fibroblast cultures by defined factors. Cell 126: 663676.

TAKEDA,K., AKAGI,S., KANAYAMA,K., KOJIMA,T., TAKAHASHI,S., IMAI,H. YAMANAKA,M., OHISHI,A., HANADA,H. (2003). Proliferation of donor mitochondrial DNA in nuclear transfer calves (Bos taurus) derived from cumulus cells. Mol Reprod Dev 64: 429-437.

TAKEDA,K., TASAI,M., IWAMOTO,M., ONISHI,A., TAGAMI,T., NIRASAWA,K., HANADA,H., PINKERT,C.A. (2005). Microinjection of cytoplasm or mitochondria derived from somatic cells affects parthenogenetic development of murine oocytes. Biol Reprod 72: 1397-1404.

TAKEDA,K., TASAI,M., AKAGI,S., MATSUKAWA,K., TAKAHASHI,S., IWAMOTO,M., SRIRATTANA,K., ONISHI,A., TAGAMI,T., NIRASAWA,K., HANADA,H., PINKERT,C.A. (2010). Microinjection of serum-starved mitochondria derived from somatic cells affects parthenogenetic development of bovine and murine oocytes. Mitochondrion 10: 137-142.

TADA,M., TADA,T., LEFEBVRE,L., BARTON,S.C., SURANI,M.A. (1997). Embryonic germ cells induce epigenetic reprogramming of somatic nucleus in hybrid cells. EMBO J. 16: 6510-6520.

TADA,M., TAKAHAMA,Y., ABE,K., NAKATSUJI,N., TADA,T. (2001). Nuclear reprogramming of somatic cells by in vitro hybridization with ES cells. Curr Biol11: 1553-1558.
TANI,T., KATO,Y., TSUNODA,Y. (2003). Reprogramming of bovine somatic cel nuclei is not directly regulated by maturation promoting factor or mitogenactivated protein kinase activity. Biol. Reprod. 69: 1890-1894.

TANI,T., SHIMADA,H., KATO,Y., TSUNODA,Y. (2007). Bovine oocytes with the potential to reprogram somatic cell nuclei have a unique 23-kDa protein, phosphorylated transcriptionally controlled tumor protei (TCTP). Cloning and Stem Cells 9: 267-280.

THUAN, N.V., WAKAYAMA,S., KISHIGAMI,S, OHTA,H., HIKICHI,T., MIZUTANI,E., BUI,H.T., WAKAYAMA,T. (2006). Injection of Somatic Cell Cytoplasm into Oocytes Before Intracytoplasmic Sperm Injection Impairs Full-Term Development and Increases Placental Weight in Mice Biol Reprod 74:865-873.

TSUJI,Y., KATO,Y., TSUNODA,Y. (2009). The developmental potential of mouse somatic cell nuclear-transferred oocytes treated with trichostatin $A$ and 5-aza2'-deoxycytidine. Zygote 17: 109-115.

TSUJI,Y., KATO,Y., TSUNODA,Y. (2010). Effect of Human Chorionic Gonadotropin and Progesterone Administration on the Developmental Potential of Mouse Somatic Cell Nuclear-Transferred Oocytes. Cell Reprog 12: 183-189.

TSUNODA, Y., KATO,Y. (1995). Development of enucleated mouse oocytes receiving fetal male germ cells treated with PDGF and FGF after activation with electrical stimulation. J Reprod Dev 41: 71-75.

TSUNODA,Y., KATO,Y. (1998). Not only inner cell mass cell nuclei but also trophectoderm nuclei of mouse blastocysts have a developmental totipotency. J Repord Fertil 113: 181-184.

TSUNODA, Y., KATO,Y. (2002). Recent progress and problems in animal cloning Differentiation 69: 158-161.

VIGNON,X., ZHOU,Q., RENARD,J.P. (2002). Chromatin as a regulative architecture of the early developmental functions of mammalian embryos after fertilization or nuclear transfer. Cloning Stem Cells 4: 363-377.

WAKAYAMA,T., PERRY,A.C., ZUCCOTTI,M., JOHNSON,K.R., YANAGIMACHI,R. (1998). Full-term development of mice from enucleated oocytes injected with cumulus cell nuclei. Nature 394: 369-374.

WAKAYAMA,T. and YANAGIMACHI,R.(1999a). Cloning of male mice from adult tail-tip cells. Nat Genet 22: 127-128.

WAKAYAMA,T., RODRIGUEZ,I., PERRY,A.C., YANAGIMACHI,R., and MOMBAERTS, P. (1999b). Mice cloned from embryonic stem cells. Proc Nat Acad Sci USA 96: 14984-14989.

WAKAYAMA,T., TATENO,H., MOMBAERTS,P., YANAGIMACHI,R. (2000). Nuclear transfer into mouse zygotes. Nat Genet 24: 108-109.

WANI,N.A., WERNERY,U., HASSAN,F.A., WERNERY,R., SKIDMORE,J.A. (2010) Production of the first cloned camel by somatic cell nuclear transfer. Biol Reprod 82: 373-379

WILMUT, I., SCHNIEKE,A.E., McWHIR,J., KIND,A.J., CAMPBELL,K.H. (1997) Viable offspring derived from fetal and adult mammalian cells. Nature 385: 810 813.

WOODS,G.L., WHITE,K.L., VANDERWALL,D.K., LI,G.P., ASTON,K.I., BUNCH,T.D., MEERDO,L.N., PATE,B.J. (2003). A mule cloned from fetal cells by nuclear transfer. Science 301: 1063.

YABUUCHIM,A., TANI,T., KATO,Y., TSUNODA,Y. (2001). Nuclear transfer of mouse follicular epithelial cells pretreated with spermine, protamine, or putrecine. J Exp Zool 289: 208-212.

YAMAZAKI,Y., MAKINO,H., HAMAGUCHI-HAMADA,K., HAMADA,S., SUGINO,H. KAWASE,E., MIYATA,T., OGAWA,M., YANAGIMACHI,R., YAGI,T. (2001). Assessment of the developmental totipotency of neural cells in the cerebral cortex of mouse embryo by nuclear transfer. Proc Natl Acad Sci USA 98: 14022 14026

YIN,XI,JUN, TANI,T., KATO,Y., TSUNODA,Y. (2002). Production of cloned pigs from adult somatic cells by chemically assisted removal of maternal chromosomes. Biol Reprod 67: 442-446.

ZHOU,Q., RENARD,J.P., LE,FRIEX,G., BROCHARD,V., BEAUJEAN, N., CHERIFI,Y., FRAICHARD,A., COZZI, J. (2003). Generation of fertile cloned rats by regulating oocyte activation. Science 302: 1179.

ZOU,X., CHEN,Y., WANG,Y., LUO, J., ZHANG, Q., ZHANG, X., YANG,Y., JU, H., SHEN,Y., LAO,W., XU,S., DU,M. (2001). Production of cloned goats from enucleated oocytes injected with cumulus cell nuclei or fused with cumulus cells. Cloning 3: 31-37. 


\section{Further Related Reading, published previously in the Int. J. Dev. Biol.}

See our recent Special Issue Placenta edited by Joan S. Hunt and Kent L. Thornburg at: http://www.ijdb.ehu.es/web/contents.php?vol=54\&issue=2-3

Enhancing somatic nuclear reprogramming by Oct4 gain-of-function in cloned mouse embryos Martin J. Pfeiffer, Sebastian T. Balbach, Telma C. Esteves, Nicola Crosetto and Michele Boiani Int. J. Dev. Biol. (doi: 10.1387/ijdb.103197mp)

Uteroplacental vascular development and placental function: an update Lawrence P. Reynolds, Pawel P. Borowicz, Joel S. Caton, Kimberly A. Vonnahme, Justin S. Luther, David S. Buchanan, Shireen A. Hafez, Anna T. GrazulBilska and Dale A. Redmer Int. J. Dev. Biol. (2010) 54: 355-365

Factors engaged in reactivation of DNA replication in the nuclei of growing mouse oocytes introduced into the cytoplasm of parthenogenetic onecell embryos

Ewa Borsuk and Renata Czolowska

Int. J. Dev. Biol. (2010) 54: 21-31

Dynamic alterations of linker histone variants during development

James S. Godde and Kiyoe Ura

Int. J. Dev. Biol. (2009) 53: 215-224

Interplay between DNA methylation, histone modification and chromatin remodeling in stem cells and during development Kohta Ikegami, Jun Ohgane, Satoshi Tanaka, Shintaro Yagi, and Kunio Shiota Int. J. Dev. Biol. (2009) 53: 203-214

The 2-cell block occurring during development of outbred mouse embryos is rescued by cytoplasmic factors present in inbred metaphase II oocytes Mario Zanoni, Silvia Garagna, Carlo A. Redi and Maurizio Zuccotti Int. J. Dev. Biol. (2009) 53: 129-134

Accessory nuclei in insect oogenesis: in search of the function of enigmatic organelles Mariusz K. Jaglarz, Malgorzata Kloc and Szczepan M. Bilinski Int. J. Dev. Biol. (2008) 52: 179-185

Cytoskeletal mechanisms of ooplasmic segregation in annelid eggs.

T Shimizu

Int. J. Dev. Biol. (1999) 43: 11-18

Effects of some cytoskeleton inhibitors on ooplasmic segregation in the Nereis virens egg. A K Dondua, R P Kostyuchenko and Z E Fedorova Int. J. Dev. Biol. (1997) 41: 853-858

Study of yolk precursor transport in the avian ovary with the use of horseradish peroxidase. K D'Herde and L Vakaet Int. J. Dev. Biol. (1992) 36: 435-438 5 yr ISI Impact Factor $(2009)=3.253$

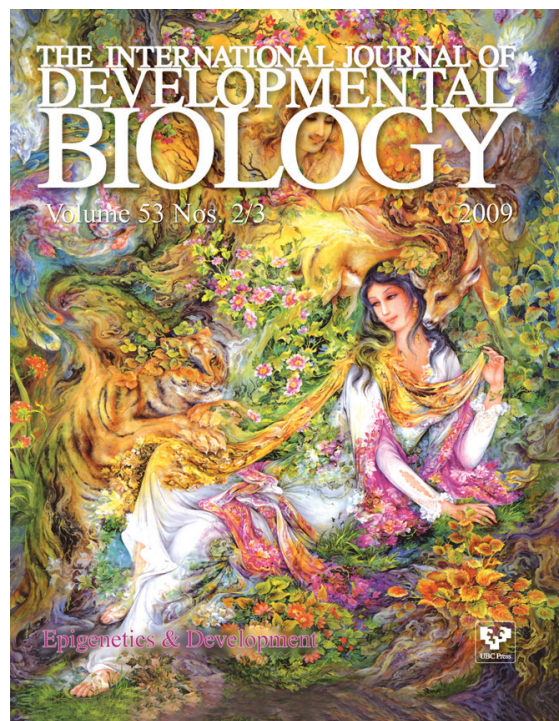

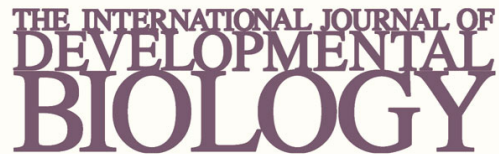

Volume 54 Nos. 6/7
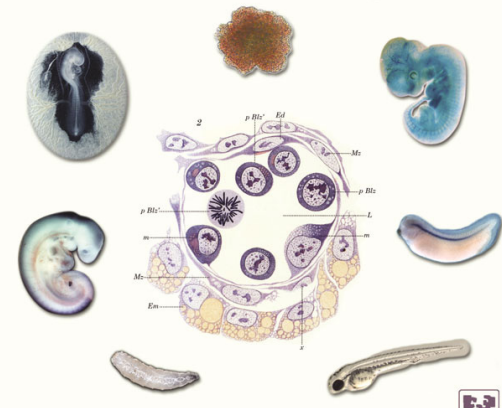

Developmental Hematopoiesis

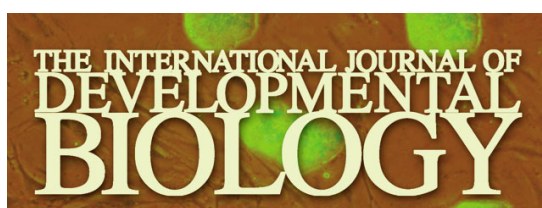

Volume 54 Nos. 11/12
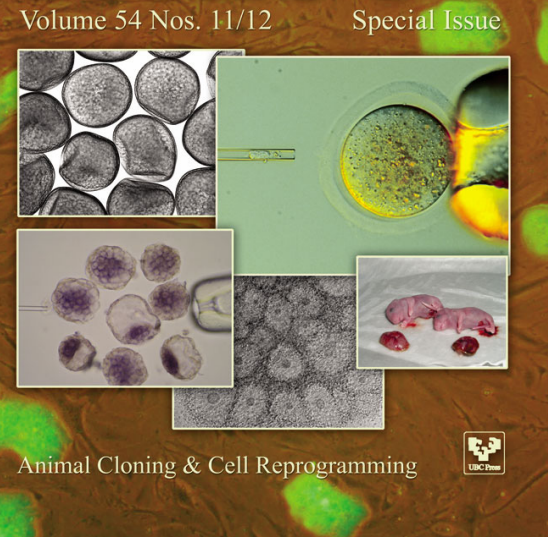